\title{
Er det nålene eller omsorgen som lindrer?
}

\begin{abstract}
Graden av samhandling mellom pasient og behandler kan påvirke resultatet av behandlingen ved irritabel tarm-syndrom.
\end{abstract}

I en ny studie ble 262 personer med irritabel tarm-syndrom randomisert til en av tre behandlingsgrupper: venteliste (observasjon), placeboakupunktur med begrenset samhandling mellom pasient og behandler eller placeboakupunktur med utvidet samhandling (1). Samhandlingen besto i empati, oppmerksomhet og fortrolighet. Studien hadde fire endepunkter: global forbedring, adekvat lindring, symptomalvorlighet og livskvalitet.

Etter tre uker var venteliste mindre effektivt enn begrenset samhandling, som igjen var mindre effektivt enn utvidet samhandling (test for trend $p<0,001$ ). Andelen pasienter i gruppen med utvidet samhandling som rapporterte adekvat lindring av symptomene, er forenlig med det man har funnet $i$ kliniske medikamentstudier av irritabel tarm-syndrom. Dette indikerer at faktorer som empati og formidling av positive forventninger påvirker det kliniske resultatet.

- At lege-pasient-forholdet er viktig for behandlingsresultatet ved mange tilstander er gammelt nytt, men betydningen er elegant demonstrert i denne studien, sier lege

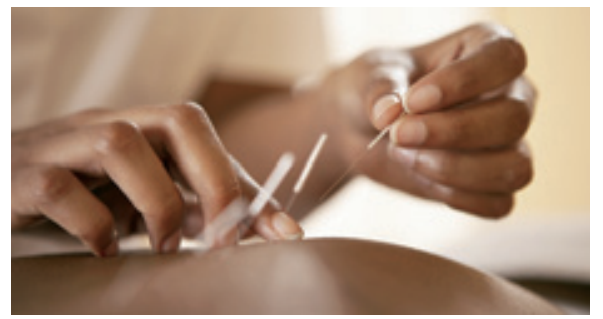

Illustrasjonsfoto GV-Press/NordicPhotos

Einar K. Borud ved Nasjonalt forskningssenter innen komplementær og alternativ medisin, Universitetet i Tromsø.

- Hensikten med placeboakupunkturen i studien var å gi en behandling som kun utløste placeboeffekter, med ikke-penetrerende nåler plassert utenfor kjente akupunkturpunkter. Imidlertid kan det settes spørsmålstegn ved om de har lyktes med dette, da det er vist at selv en slik beskjeden stimulering av huden har fysiologiske effekter, sier Borud.

\section{Merethe Kumle}

merethe.kumle@unn.no

Klinisk forskningssenter

Universitetssykehuset Nord-Norge

\section{Litteratur}

Kaptchuk TJ, Kelley JM, Conboy LA et al. Components of placebo effect: randomised controlled trial in patients with irritable bowel syndrome. BMJ 2008; 336: 999-1003.

\section{Pasientsikkerhetskultur på norsk}

\section{Den norske oversettelsen av spørre- skjemaet Safety Attitudes Question- naire har tilfredsstillende psyko- metriske egenskaper og kan brukes til å måle sikkerhetskulturen ved sengeposter, poliklinikker og andre behandlingsenheter.}

Safety Attitudes Questionnaire er et av de best validerte spørreskjemaer for å måle pasientsikkerhetskultur og det eneste som er validert mot pasientresultater. I en intervensjonsstudie i Michigan har man vist at forbedring av pasientsikkerhetskulturen korrelerer med lavere forekomst av kateterrelaterte infeksjoner i intensivavdelinger. Vi ønsket å undersøke egenskapene til den norske oversettelsen av dette spørreskjemaet.

Studien ble utført blant helsepersonell ved 47 somatiske behandlingsenheter ved Akershus universitetssykehus (1). 1911 spørreskjemaer ble distribuert til leger, sykepleiere, hjelpepleiere, sekretærer og fysioterapeuter ved sengeposter, poliklinikker, akuttmottak, intensivenhet osv. Legene og fysioterapeutene hadde anledning til å fylle ut skjemaet for inntil tre behandlingsenheter som de arbeidet ved, f.eks. sengepost, poliklinikk og akuttmottak.

1306 helsearbeidere deltok (68\%). Totalt antall observasjoner var 1460 . Konfirmerende faktoranalyse av de norske dataene viste tilfredsstillende tilpasning til spørreskjemaets opprinnelige faktorstruktur. Resultatene viste at det var størst variasjon mellom sengepost og poliklinikk, men også variasjon på avdelingsnivå.

Vi foreslår at de regionale helseforetakene måler sikkerhetskulturen i sine behandlingsenheter og iverksetter validerte forbedringstiltak der den er svak.

\section{Ellen Tveter Deilkås}

ellen.deilkaas@ahus.no

Helse Sør-Øst kompetansesenter for

helsetjenesteforskning

Akershus universitetsykehus

\section{Litteratur}

1. Deilkas E, Hofoss D. Psychometric properties of the Norwegian version of the Safety Attitudes Questionnaire (SAQ), Generic version (Short Form 2006). BMC Health Serv Res 2008; 8: 191.

\section{Gefitinib ved lungekreft}

Gefitinib kan brukes i behandlingen av ikke-småcellet lungekreft i stedet for docetaxel er konklusjonen i en randomisert fase 3-studie (Lancet 2008; 372: 1809-18).

1433 pasienter med alvorlig ikke-småcellet lungekreft som hadde fått behandling med platinabasert kjemoterapi ble randomisert til å få enten gefitinib eller docetaxel. 593 pasienter i gefitinibgruppen overlevde, mot 576 i docetaxelgruppen.

I gefitinibgruppen var de vanligste bivirkningene utslett, akne og diaré, i docetaxelgruppen var det nøytropeni, asteni og alopesi.

\section{Betainterferon ved multippel sklerose}

Rundt halvparten av pasientene med multippel sklerose behandlet med betainterferon oppnådde og opprettholdt en optimal respons på behandlingen over tid. Det viser en studie i Archives of Neurology (DOI: 10.1001/archneur.66.1.noc80047).

Forskerne undersøkte respons på behandling med betainterferon hos 15 pasienter med multippel sklerose med månedlige MR-undersøkelser i tre år. Ved hver MR-undersøkelse ble antall lesjoner notert. Respons på behandling var definert som $60 \%$ reduksjon i antall lesjoner per semester av terapi. Åtte pasienter oppnådde optimal respons, sju pasienter gjorde det ikke.

\section{Jern og nyfødtdødelighet i u-land}

Når det gjelder dødeligheten hos barn under fem år i u-land, er neonatal død viktigst. Den er forbundet med lav fødselsvekt. En av hovedårsakene til lav fødselsvekt hos disse barna er dårlig ernæring under svangerskapet. Nå har kinesiske og australske forskere sett på effekten av kosttilskudd til gravide i kinesiske landbruksområder (BMJ 2008; 337: a2001).

En dobbeltblind studie omfattet 5828 gravide som ble randomisert til å ta enten folsyre (kontrollpersoner), jern med folsyre eller et kosttilskudd bestående av 15 vitaminer og mineraler. 4697 levende barn ble født.

Jern kombinert med folsyre ga økt svangerskapslengde, redusert risiko for for tidlig fødsel og var assosiert med redusert tidlig neonatal dødelighet i forhold til folsyre alene. Kosttilskudd ga en beskjeden økning i fødselsvekten sammenliknet med folsyre, men førte ikke til noen reduksjon av tidlig neonatal dødelighet. Resultatene viser at man bør tilsette jern i kosttilskudd for gravide i u-land for å redusere nyfødtdødeligheten mest mulig. 